\title{
ANALISIS LIQUIDITY CREATION PADA PERBANKAN DI INDONESIA TAHUN 2007-2013 (STUDI KASUS PADA 10 BANK BESAR DI INDONESIA TAHUN 2013)
}

\author{
Muhammad Mirajudin*, Prasetiono ${ }^{1}$ \\ muhammad.mirajudin@gmail.com \\ Program Studi Manajemen \\ Fakultas Ekonomika dan Bisnis \\ Universitas Diponegoro \\ Received 1 April 2015 \\ Received in revised form 1 May 2015 \\ Accepted 1 June 2015
}

\begin{abstract}
Problems related to banking in Indonesia today is the problem of liquidity. It is shown from a commercial bank credit grew $23.03 \%$ but not matched by growth in deposits which only reached 16.56\% in 2012 (Report of Banking Supervision, 2012). Therefore, this study aims to determine the liquidity creation in Indonesia as well as to analyze the influence of bank capital, credit risk and income instability towards liquidity creation. The samples includes 10 major banks in Indonesia with total assets of more than Rp120billion in 2013. The reason for choosing this sample because of the 10 largest banks reflects the state of the banks in Indonesia which accounted for $65.2 \%$ of total assets, $65.6 \%$ of total loans, and $66 \%$ of total deposits or deposits in the banking industry (PEFINDO, 2014). The results of this research note that the bank's capital and earnings volatility is significant negative effect on liquidity creation. While the credit risk of a negative but insignificant effect on liquidity creation. In the determination coefficient test showed that $43.6 \%$ dependent variable is the liquidity creation can be explained by the independent variable is the capital of banks, credit risk and earnings volatility. While $56.4 \%$ is explained by other variables outside the model of this study.
\end{abstract}

Keywords: liquidity creation, capital of banks, credit risk, third-party funds, banks in Indonesia.

\section{PENDAHULUAN}

Bank merupakan jembatan dalam proses kegiatan ekonomi. Karena berfungsi sebagai penghubung antara mayarakat yang kelebihan dana dan masyarakat yang membutuhkan dana. Kegiatan bank tersebut merupakan fungsi intermediasi dari bank itu sendiri (Mishkin, 2008). Perbankan memainkan peranan yang penting dalam kegiatan perekonomian bagi suatu negara. Karena tugas utama bank sebagai lembaga intermediasi adalah menyimpan dana masyarakat. Dalam simpanan itu masyarakat berharap tabungannya aman, sehingga bisa diambil sewaktu-waktu apabila dibutuhkan. Selain itu bank juga menyalurkan dananya dalam bentuk kredit, sebagai pembiayaan bagi usaha masyarakat. Untuk itu bank harus 
selektif dalam memilih kredit yang produktif, sehingga mendatangkan keuntungan bagi bank itu sendiri.

Sebagai lembaga intermediasi, kegiatan bank dalam prosesnya menyangkut dengan likuiditas. Likuiditas merupakan kemampuan bank dalam memenuhi kewajiban jangka pendek dengan harta lancarnya. Dengan kata lain jika seorang deposan akan mengambil uangnya sewaktu-waktu, maka bank bisa memenuhinya dengan harta lancarnya dalam jangka pendek (Taswan, 2006). Bank membentuk likuiditas (liquidity creation) menggunakan aset yang relatif likuid dengan kewajiban yang relatif likuid. Bentuknya yaitu berupa dana cair yang ada di bank, yang dapat dijadikan sebagai dana likuiditas maupun sebagai dana peneyerapan risiko (Bryant, 1980; Diamond dan Dybvig, 1983 dalam Berger dan Bouwman, 2007).

Berger dan Bouwman (2007) menjelaskan bahwa liquidity creation sangat penting dalam kegiatan maupun peran bank. Namun perhitungan dan langkah-langkah komprehensif mengenai liquidity creation tersebut belum ada. Dalam penelitian Berger dan Bouwman (2006, 2007) yang berjudul "The Measurement of Bank Liquidity Creation and the Effect of Capital" dan "Bank Liquidity Creation" yang menjadi acuan dari penelitian ini. Dalam penelitian tersebut membuat tiga langkah perhitungan liquidity creation dan menerapkannya pada bank di Amerika dari tahun 1993 - 2003. Hasil penelitian tersebut menerangkan bahwa bank liquidity creation di Amerika mengalami kenaikan setiap tahunnya. Pada tahun 2003 liquidity creation pada bank di Amerika Serikat mencapai \$2.8 triliun. Selain itu $\$ 1$ dari modal bank membuat liquidity creation sebesar \$4,56 pada perbankan di Amerika pada tahun 1993 - 2003 (Berger dan Bouwman, 2006, 2007).
Dalam penelitian ini, variabel yang digunakan dalam mempengaruhi liquidity creation adalah permodalan bank, risiko kredit dan earning volatility. Modal bank atau equity ratio (EQRAT) yaitu total ekuitas dibanding dengan total aset (Berger dan Bouwman, 2009). Risiko kredit dalam penelitian ini menggunakan perhitungan aktiva tertimbang menurut risiko kredit dibanding dengan total aset (Lei dan Song, 2013). Ketidakstabilan pendapatan atau earning volatility merupakan standar deviasi dari return on asset selama 5 tahun terakhir (Horváth, 2012).

Ada beberapa perbedaan hasil dari beberapa penelitian terdahulu yang menjadi research gap dalam penelitian ini. Berger dan Bouwman (2009) menyatakan bahwa pengaruh modal terhadap liquidity creation bersifat positif, berbeda dengan hasil dari penelitian Lei dan Song (2013) bahwa pengaruh modal bank terhadap liquidity creation adalah negatif. Hasil penelitian Horváth et al., (2012) dan Lei dan Song (2013) menyatakan bahwa pengaruh risiko kredit terhadap liquidity creation adalah positif, berbeda dengan hasil dari penelitian Fungáčová et al., (2010) yang menyatakan bahwa risiko kredit yang diproyeksian dengan nonperforming loans (NPL) terhadap liquidity creation adalah negatif. Dari hasil penelitian Horváth et al., (2012) menyatakan bahwa pengaruh earning volatility terhadap liquidity creation adalah positif. Sementara itu hasil penelitian Lei dan Song (2013) menyatakan pengaruh earning volatility terhadap liquidity creation adalah negatif.

Selain reseach gap, terdapat pula fenomena gap dalam penelitian ini yaitu adanya perbedaan teori antara risk absorption yang dikemukakan oleh Bhattacharya et al., (1993); Repullo (2004); Von Thadden (2004) dengan teori bank fragility-crowding out (Diamond dan Rajan, 2000,2001; 
Gorton dan Winton, 2000). Selain perbedaan teori, terdapat pula keadaan likuiditas di Indonesia yang melemah (LDR meningkat tajam) dan adanya fluktuasi nilai pada variabel penelitian ini sehingga terjadi inkonsistensi dengan teori risk absorption (Bhattacharya et al., 1993; Repullo, 2004); Von Thadden, 2004).

Tujuan dalam penelitian ini yaitu untuk mengetahui dan menganalisis pengaruh yang terjadi pada modal bank, risiko kredit dan ketidakstabilan pendapatan (earning volatility) terhadap liquidity creation.

\section{KERANGKA TEORITIS DAN HIPOTESIS \\ PEMIKIRAN}

Ada beberapa teori yang menjadi kerangka pemikiran dalam penelitian mengenai hubungan modal bank dengan liquidity creation. Pada teori pertama "bank financial fragility", teori ini menyatakan bahwa modal bank yang mengalami kenaikan akan menurunkan tingkat liquidity creation (Diamond and Rajan, 2000, 2001). Dalam teori bank financial fragility bank tidak menahan atau menyimpan modal apapun. Melainkan mengembalikan modal tersebut kembali ke masyarakat melalui kredit yang diberikan. Jika bank terlalu gencar dalam penyaluran kredit tersebut maka kemampuan bank untuk liquidity creation tersebut akan menurun. Oleh sebab itu modal bank yang meningkat dapat menghambat penciptaan likuiditas dan mempunyai hubungan yang negatif. Hal ini terjadi karena banyaknya kredit yang diberikan dibanding dengan penyediaan likuiditas pada bank tersebut. Teori kedua adalah "crowding out" yang dikemukakan oleh Gorton dan Winton (2000). Teori ini menjelaskan bahwa rasio modal yang lebih tinggi akan dapat merubah dana pihak ketiga menjadi kredit yang lebih besar, dengan demikian mengurangi liquidity creation.
Kedua teori di atas yang sekarang disebut sebagai "financial fragilitycrowding out" (Diamond and Rajan, 2000, 2001; Gorton dan Winton, 2000). Bank menghimpun dana dari masyarakat berupa deposito, kemudian membentuknya menjadi kredit yang produktif. Sehingga membuat ketersediaan dana untuk depositor lebih kecil dibandingkan dengan kredit yang diberikan. Dengan kata lain ada penyaluran dana yang tinggi dari dana deposito ke dalam bentuk kredit, yang mengakibatkan ketersediaan dana untuk membentuk likuiditas lebih kecil. Hal ini menandakan bahwa rasio permodalan bank yang tinggi akan menurunkan tingkat liquidity creation. Dengan demikian pengaruh modal terhadap liquidity creation adalah negatif.

Dalam teori "risk absorption" yang dikemukakan oleh Bhattacharya et al., (1993); Repullo (2004); Von Thadden (2004) dalam Berger dan Bouwman (2007), teori ini memiliki pandangan yang berbeda mengenai hubungan modal dengan liquidity creation. Dalam prosesnya modal yang tinggi akan ditahan oleh bank, untuk membuat bank lebih mampu menyerap risiko. Sehingga memungkinkan bank untuk lebih banyak membuat likuiditas. Hal tersebut memungkinkan bank mampu menyediakan dana yang banyak, jika sewaktu-waktu para depositor menarik uangnya di bank. Teori risk absorption menunjukan bahwa modal yang tinggi dapat membentuk liquidity creation yang tinggi pula dan hubungannya adalah positif. Menurut Berger dan Bouwman (2007) alasan bank menahan modalnya yaitu untuk membentuk liquidity creation. Bank menahan modalnya untuk keperluan nasabah jika sewaktu-waktu dana tersebut ditarik kembali. Selain itu bank menahan modalnya untuk bertahan dari berbagai risiko, seperti risiko likuiditas, risiko kredit, bank runs dan risiko lainnya. 
Sebuah pandangan alternatif lain, yang terkait dengan bank berfungsi sebagai risk transformers. Mengindetifikasikan bahwa modal yang lebih tinggi dapat meningkatkan kemampuan bank untuk menyerap risiko. Dengan begitu, akan meningkatkan kemampuan bank untuk menciptakan likuiditas. Liquidity creation menghadapkan pada risiko. Semakin besar likuiditas bank dibuat, maka semakin besar pula adanya kemungkinan kerugian yang terjadi. Hal tersebut karena bank harus mengorbankan aset lancar untuk memenuhi kebutuhan likuiditas nasabah (Diamond and Dybvig, 1983; Allen dan Santomeru, 1998; Allen and Gale, 2003). Menurut Bhattacharya et al., (1993); Repullo (2004) Von Thadden (2004) menyatakan bahwa modal yang tinggi mampu menyerap risiko. Sehingga dengan ketersediaan dana yang besar, bank mampu meminimalisir terjadinya risiko. Hal tersebut memungkinkan bank dapat menciptakan lebih banyak likuiditas karena adanya ketersediaan dana yang banyak. Sehingga hubungan modal dengan liquidity creation tersebut adalah positif.

Gambar 1

Kerangka Pemikiran

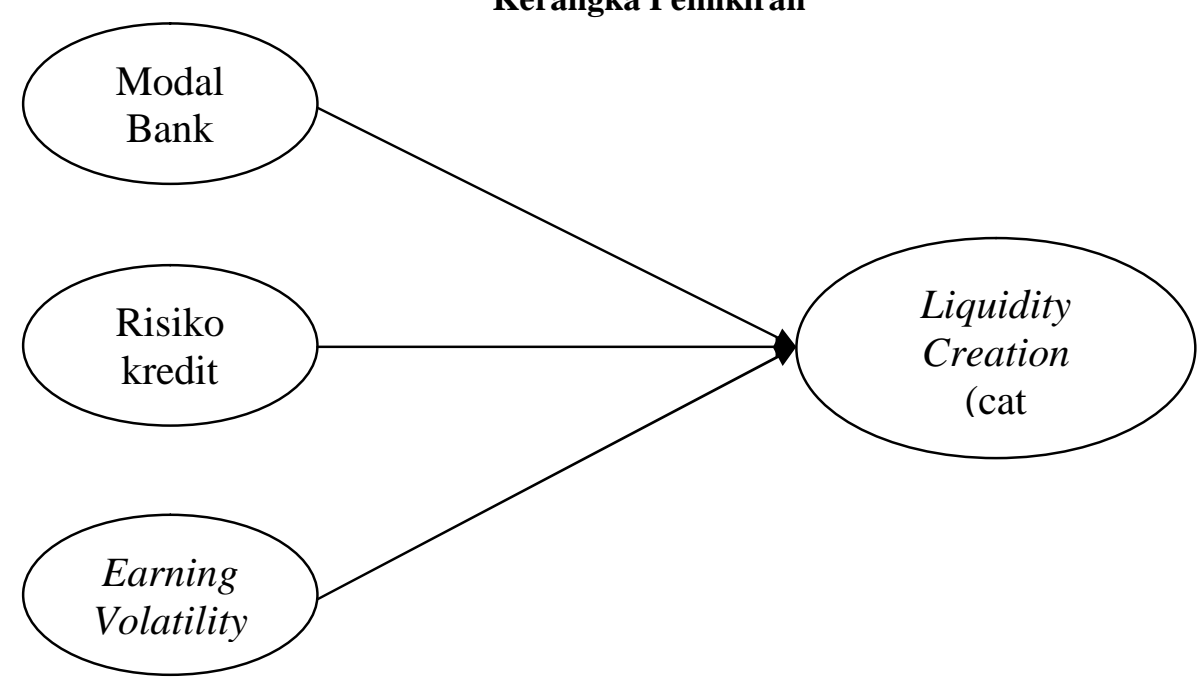

Sumber: $\quad$ Berger dan Bouwman (2007). Chorvath, Seidler dan Weill (2012). Lin, Yon Jia (2014). Lei dan Song (2013)

\section{Pengaruh modal bank (EQRAT) terhadap liquidity creation}

Salah satu tujuan dalam penelitian ini adalah mengindetifikasi pengaruh modal bank terhadap liquidity creation. dengan sampel pada bank di Indonesia tahun 2007 - 2013. Permodalan bank dapat mempengaruhi liquidity creation (Berger dan Bouwman, 2009; Horváth et al., 2012; Lei dan Song, 2013). Karena modal bank merupakan sumber utama dalam kegiatan intermediasi, yang termasuk di dalamnya ada kegiatan pembentukan likuditas. Permodalan bank yang kuat akan lebih banyak membentuk likuiditas.

Dalam teori risk absorption (Bhattacharya et al., 1993; Repullo, 2004; Von Thadden, 2004) dalam Berger dan Bouwman (2007). Dalam prosesnya modal yang tinggi akan ditahan oleh bank, untuk membuat bank lebih mampu menyerap risiko. Sehingga memungkinkan bank untuk lebih banyak membuat likuiditas. Hal tersebut memungkinkan bank mampu 
menyediakan dana yang banyak, jika sewaktu-waktu para depositor menarik uangnnya di bank. Dengan demikian dalam teori ini permodalah yang tinggi dapat meningkatkan liquidity creation.

Namun dalam teori "financial fragility-crowding out" (Diamond dan Rajan, 2000, 2001; Gorton dan Winton, 2000). Bank menghimpun dana dari masyarakat berupa deposito, kemudian membentuknya menjadi kredit yang produktif. Sehingga bagian dari ketersediaan dana untuk depositor lebih kecil dibandingkan dengan kredit yang di berikan. Akibatnya ada penyaluran dana yang lebih besar dari dana deposito ke dalam bentuk kredit. Sehingga mengakibatkan ketersediaan dana untuk membentuk likuiditas lebih kecil.

Hal tersebut di atas menandakan bahwa rasio permodalan bank yang tinggi, akan menurunkan tingkat liquidity creation. Dengan demikian pengaruh modal terhadap liquidity creation adalah negatif. Seperti masalah yang terjadi di Indonesia karena penyaluran dana yang lebih besar daripada pertumbuhan dana pihak ketiga menyebabkan penyediaan dana terhadap liquidity creation menurun. (Laporan Pengawasan Perbankan, 2012). Karena penelitian ini menggunakan sampel pada bank di Indonesia, dengan demikian hipotesis yang diajukan:

$\mathrm{H}_{1}=$ modal bank berpengaruh negatif pada liquidity creation.

Pengaruh risiko kredit terhadap liquidity creation

Faktor lain yang mempengaruhi liquidity creation yaitu risiko kredit (Berger dan Bouwman, 2007; Horváth et al., 2012; Lei dan Song, 2013). Risiko kredit merupakan risiko yang timbul karena debitur tidak dapat memenuhi kewajibannya pada bank pada saat jatuh tempo. Berger dan Bouwman (2009) menyatakan bahwa liquidity creation terjadi seiring dengan timbulnya risiko pada bank.
Dalam teori risk transformers (Diamond, 1984; Ramakhrishnan dan Thakor, 1984; Boyd dan Prescott, 1986) menyatakan bahwa bank mentransformasi risiko menggunakan dana deposito yang mempunyai risiko rendah menjadi kredit dengan risiko yang lebih tinggi. Artinya jika semakin tinggi risiko kredit pada bank, maka bank akan bertindak menahan modalnya untuk keperluan penyerapan risiko kredit.

Liquidity creation terjadi seiring dengan timbulnya risiko, untuk itu jika risiko kredit timbul maka bank akan mengantisipasi dana untuk keperluan likuiditas supaya tidak terkena efek akibat timbulnya risiko kredit tersebut (Berger dan Bouwman, 2009). Dari hasil penelitian Horváth et al., (2012); Lei dan Song (2013) menyatakan bahwa hubungan risiko kredit dengan liquidity creation adalah positif. Jika risiko kredit yang terjadi pada bank mengalami kenaikan maka liquidity creation juga akan mengalami kenaikan. Dengan demikian hipotesis yang diajukan:

$\mathbf{H}_{2}=$ risiko kredit pada bank berpengaruh positif terhadap liquidity creation.

Pengaruh ketidakstabilan pendapatan (earning volatility) terhadap liquidity creation

Selain risiko kredit, risiko lainnya yang mempengaruhi liquidity creation adalah earning volatility atau ketidakstabilan pendapatan (Horvath et al., 2012; Lei dan Song, 2013). Earning volatility juga digunakan para peneliti sebagai faktor yang mempengaruhi liquidity creation pada perbankan. Hasil dari penelitian Horvath et al., (2012) menyatakan bahwa, earning volatility berpengaruh positif terhadap liquidity creation. Hal ini terjadi karena semakin tinggi ketidakstabilan pendapatan pada bank, maka bank harus berhati-hati dalam alokasi modalnya. Kehati-hatian ini disebabkan karena bank menahan modalnya untuk meminimalisir risiko 
yang ada, sehingga dana yang tersedia cukup banyak untuk memenuhi kebutuhan likuiditas. Dengan demikian hipotesis yang diajukan:

$\mathrm{H}_{3}=$ earning volatility berpengaruh positif terhadap liquidity creation.

\section{METODE PENELITIAN} Variabel Penelitian

\begin{abstract}
Dalam penelitian ini perhitungan liquidity creation menggunakan perumusan yang dikemukakan oleh Distinguin et al., (2013) yang menggunakan klasifikasi perhitungan liquidity creation oleh Berger dan Bouwman (2006, 2007), perumusan liquidity creation pada penelitian ini sebagai berikut berikut :
\end{abstract}

$$
L C=\frac{\begin{array}{c}
0,5 * \text { illiquid assets }+0 * \text { semiliquid assets }-0,5 \text { liquid asset } \\
+0,5 \text { liquid liabilities }+0 * \text { semiliquid liabilites }-0,5 * \text { illiquid liabilities }
\end{array}}{\text { lviul equily }}
$$

Sumber : Distinguin et al., (2013)

Variabel yang digunakan dalam mempengaruhi liquidity creation dalam penelitian ini adalah permodalan bank, risiko kredit dan earning volatility. Modal bank atau equity ratio (EQRAT) yaitu total ekuitas dibanding dengan total aset (Berger dan Bouwman, 2009). Risiko kredit dalam penelitian ini menggunakan perhitungan aktiva tertimbang menurut risiko kredit ditambah dengan aktivitas off balance sheet dibanding dengan total aset (Lei dan Song, 2013). Ketidakstabilan pendapatan atau earning volatility merupakan standar deviasi dari return on asset selama 5 tahun terakhir (Horváth, 2012).

\section{Penentuan Sampel}

Data yang diteliti pada perbankan di Indonesia dari tahun 2007 - 2013. Sampel yang digunakan dalam penelitian temasuk 10 bank terbesar di Indonesia pada tahun 2013 dengan total aset lebih dari 120 triliun rupiah. Alasan memilih sampel dari 10 bank terbesar tersebut menyumbang $65,2 \%$ dari total asset, $65,6 \%$ dari total kredit, dan $66 \%$ dari total dana pihak ketiga atau simpanan di industri perbankan (PEFINDO, 2014).

Pada tabel 1 dibawah ini merupakan data yang termasuk dari 10 bank besar di Indonesia perdesember 2013 (Infobank, Juni 2014).

Tabel 1

\begin{tabular}{|c|c|c|c|c|c|}
\hline No & Nama Bank & Asset & $\begin{array}{l}\text { Modal } \\
\text { Inti }\end{array}$ & DPK & Kredit \\
\hline 1 & PT. Bank Mandiri, Tbk & 733,09 & 71,60 & 556,34 & 471,82 \\
\hline 2 & $\begin{array}{l}\text { PT. Bank Rakyat Indonesia, } \\
\text { Tbk }\end{array}$ & 626,18 & 67,26 & 504,28 & 448,10 \\
\hline 3 & PT. Bank Central Asia Tbk & 496,30 & 54,73 & 411,18 & 313,71 \\
\hline 4 & $\begin{array}{l}\text { PT. Bank Negara Indonesia, } \\
\text { Tbk }\end{array}$ & 386,65 & 41,51 & 291,89 & 250,45 \\
\hline 5 & PT. Bank CIMB Niaga, Tbk & 218,86 & 23,43 & 163,74 & 156,98 \\
\hline 6 & $\begin{array}{l}\text { PT. Bank Danamon } \\
\text { Indonesia, Tbk }\end{array}$ & 184,23 & 26,79 & 109,16 & 133,87 \\
\hline 7 & PT. Bank Permata, Tbk & 165,83 & 11,77 & 132,77 & 118,83 \\
\hline 8 & PT. Pan Indonesia Bank, Tbk & 164,05 & 16,83 & 120,26 & 110,75 \\
\hline 9 & $\begin{array}{l}\text { PT. Bank Internasional } \\
\text { Indonesia, Tbk }\end{array}$ & 140,71 & 10,51 & 107,24 & 102,03 \\
\hline 10 & PT. Bank Tabungan Negara, & 131,16 & 9,87 & 96,21 & 100,47 \\
\hline
\end{tabular}

Sampel Penelitian pada 10 bank Besar di Indonesia tahun 2013 (dalam triliun rupiah) 
Tbk

Sumber : Laporan keuangan bank dan Majalah Infobank (Juni, 2014)

Jumlah sampel dalam penelitian ini sebanyak 70 data $(7$ tahun $\times 10$ bank). Angka tersebut di dapatkan dari jumlah tahun dalam penelitian ini (2007$2013=7$ tahun) dan jumlah objek dalam penelitian ini (10 bank besar).

\section{Metode Analisis}

Penelitian ini menggunakan metode analisis regresi linear berganda, namun sebelum melakukan analisis dilakukan terlebih dahulu uji asumsi klasik dan uji kelayakan model (goodness of Fit). Analisis linear berganda bertujuan untuk menguji pengaruh modal bank (EQRAT), risiko kredit, earning volatility terhadap liquidity creation dengan persamaan sebagai berikut ini :

$\mathrm{Y}=\mathrm{a}+\mathrm{b}_{1} \mathrm{x}_{1}+\mathrm{b}_{2} \mathrm{x}_{2}+\mathrm{b}_{3} \mathrm{x}_{3}+\mathrm{e}$

Keterangan :

$\mathrm{Y} \quad=$ Liquidity Creation

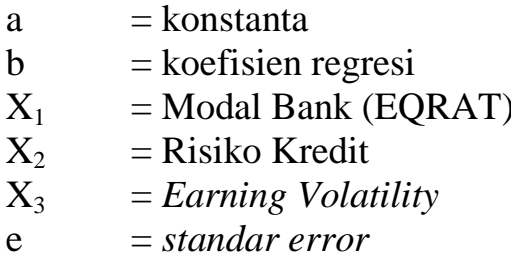

\section{HASIL PENELITIAN DAN PEMBAHASAN \\ Deskripsi Sampel Penelitian}

Data 10 bank besar di Indonesia yang diklasifikasikan menurut aset, modal inti, DPK dan penyaluran kredit pada bulan desember tahun 2013. Data tersebut diperoleh dari laporan keuangan masing-masing bank dan peringkat 10 bank besar tersebut diambil dari Majalah Infobank bulan Juni tahun 2014. Dibawah ini merupakan Uji Deskriptif pada 10 bank besar.

Tabel 2

Uji Deskriptif Klasifikasi 10 Bank Besar di Indonesia tahun 2013

\begin{tabular}{lrrrrr}
\hline & Asset & \multicolumn{2}{c}{ Modal } & DPK & Kredit \\
$\mathrm{N}$ & Valid & 10 & 10 & 10 & 10 \\
& Missing & 0 & 0 & 0 & 0 \\
\hline Mean & 324,7060 & 33,4300 & 249,3070 & 220,7010 \\
Median & 201,5450 & 25,1100 & 148,2550 & 145,4250 \\
Std. Deviation & 222,17336 & 23,78048 & 178,92124 & 144,11105 \\
Range & 601,93 & 61,73 & 460,13 & 371,35 \\
Minimum & 131,16 & 9,87 & 96,21 & 100,47 \\
Maximum & 733,09 & 71,60 & 556,34 & 471,82 \\
\hline : Data Olahan Sendiri mengounakan IBM SPSS Statistics 21
\end{tabular}

Berdasarkan pada Tabel 2 memperlihatkan bahwa nilai rata-rata aset sebesar 324,7. Hal ini berarti ratarata aset yang dimiliki oleh 10 bank besar di Indonesia sebesar Rp 324,7 trilliun. Nilai aset paling tinggi dimiliki oleh PT. Bank Mandiri, Tbk yaitu dengan nilai total aset sebesar Rp 733,09 triliun. Nilai minimum aset yang paling kecil dimiliki oleh PT. Bank Tabungan Negara, Tbk dengan nilai total aset Rp 131,16 trilliun pada bulan juni 2014.

\section{Uji Asumsi Klasik}

Uji asumsi klasik yang pertama adalah uji normalitas data yang bertujuan untuk menguji apakah dalam model regresi, variabel pengganggu atau residual memiliki distribusi normal (Ghozali, 2013). Uji normalitas menggunakan uji one sample Kolmogorov-Smirnov Test. Syarat data yang berdistribusi normal yaitu dengan melihat tingkat signifikasi atau Asymp. Sig (2-tailed). Jika signifikasi lebih 
besar dari 0,05 maka data berdistribusi normal, sebaliknya jika lebih kecil dari 0,05 maka data pada sampel tidak lolos uji normalitas. Hasil dari Uji Normalitas data menggunakan uji K-S dalam penelitian ini sebagai berikut :

Tabel 3

Uji Normalitas Data

One-Sample Kolmogorov-Smirnov Test

\begin{tabular}{llr}
\hline & & $\begin{array}{c}\text { Unstandardized } \\
\text { Residual }\end{array}$ \\
N & Mean & 70 \\
\hline Normal Parameters & & .0000000 \\
& Std. Deviation & .53822420 \\
Most Extreme Differences & Absolute & .076 \\
& Positive & .050 \\
Kolmogorov-Smirnov Z & Negative & -.076 \\
Asymp. Sig. (2-tailed) & & .632 \\
\hline a. Test distribution is Normal. & .819 \\
b. Calculated from data &
\end{tabular}

Sumber : Data Olahan Sendiri menggunakan IBM SPSS Statistics 21

Berdasarkan pada tabel 3 diperlihatkan bahwa nilai signifikansi pada Asymp. Sig. (2-tailed) sebesar 0,819. Dengan nilai Asymp. Sig. (2tailed) sebesar 0,819 yang lebih besar dari 0,05. Maka dalam penelitian ini data sampel tersebar secara normal. Hal tersebut menyatakan bahwa model regresi dalam penelitian ini memenuhi asumsi uji normalitas.

Uji asumsi klasik yang kedua adalah Uji Multikolinearitas uang bertujuan untuk melihat ada atau tidaknya korelasi antar variabel independen pada model regresi. Untuk mengetahui apakah terjadi multikolinearitas atau tidak dalam model regresi yaitu dengan melihat nilai tolerance serta Variance Inflation Factor (VIF). Adanya multikolinearitas antar variabel ditunjukan dengan nilai tolerance $>0,10$ dan nilai $\mathrm{VIF}<10$ (Ghozali, 2013). Hasil dari uji multikolinearitas sebagai berikut:

Tabel 4

Uji Multikolinearitas

Coefficients $^{\mathrm{a}}$

\begin{tabular}{|c|c|c|c|}
\hline \multirow[t]{2}{*}{ Model } & & \multicolumn{2}{|c|}{ Collinearity Statistics } \\
\hline & & Tolerance & VIF \\
\hline \multirow{4}{*}{1} & (Constant) & & \\
\hline & EQRAT & .787 & 1.270 \\
\hline & EARNVOL & .841 & 1.189 \\
\hline & CREDITRISK & .888 & 1.126 \\
\hline
\end{tabular}

a. Dependent Variable: LIQUIDITY CREATION

Sumber : Data Olahan Sendiri menggunakan IBM SPSS Statistics 21. 
Berdasarkan pada tabel 4 menunjukan nilai tolerance pada variabel modal (EQRAT) sebesar 0,787, risiko kredit (CREDITRISK) sebesar 0.888 , earning volatility (EARNVOL) sebesar 0,841. Hal ini menunjukan bahwa nilai tolerance dari masingmasing variabel lebih besar dari 0,10 . Nilai VIF pada variabel modal (EQRAT) sebesar 1,270, risiko kredit (CREDITRISK) sebesar 1,126, earning volatility (EARNVOL) sebesar 1,189. Dengan demikian nilai VIF dari masingmasing variabel dibawah 10 . Karena nilai tolerance lebih dari 0,10 dan nilai VIF di bawah 10 maka korelasi antar variabel dalam model regresi pada penelitian ini tidak terdapat multikolinearitas.
Uji asumsi klasik yang ketiga adalah uji autokorelasi yang bertujuan mengetahui apakah model regresi linier ada korelasi antara kesalahan pengganggu pada periode $t$ dengan kesalahan pengganggu pada periode sebelumnya ( $\mathrm{t}-1)$. Model regresi mensyaratkan tidak boleh terjadi autokorelasi. Cara mendeteksi gejala autokorelasi dalam penelitian ini menggunakan Uji Durbin-Watson (DW test). Menurut Ghozali (2014) model terbebas dari masalah autokorelasi bila nilai DW diantara DU sampai dengan 4DU. Nilai DU dengan jumlah variabel independen 4, tingkat signifikansi 5\% maka DU tabel sebesar 1,7028. Hasil selengkapnya tersaji pada tabel berikut:

Tabel 5

Model Summary ${ }^{\mathrm{b}}$

\begin{tabular}{lrrrrr}
\hline Model & R & R Square & $\begin{array}{c}\text { Adjusted R } \\
\text { Square }\end{array}$ & $\begin{array}{c}\text { Std. Error of the } \\
\text { Estimate }\end{array}$ & Durbin-Watson \\
\hline 1 & $.678^{\mathrm{a}}$ & .460 & .436 & .55032063 & 1.732
\end{tabular}

a. Predictors: (Constant), CREDITRISK, EARNVOL, EQRAT

b. Dependent Variable: LIQUIDITY

Sumber : Data Olahan Sendiri menggunakan IBM SPSS Statistics 21

\section{Uji Auto Korelasi Durbin-Watson}

Berdasarkan pada tabel 5 pengujian autokorelasi dengan Durbin Watson Test didapatkan nilai DW hitung sebesar 1,732. Dimana angka DW ini lebih besar dari nilai DU yaitu 1,7028 dan lebih kecil dari nilai 4-DU $=2,2972$ yang berarti tidak terdapat autokorelasi negatif atau positif. Maka dapat disimpulkan model tidak mengandung masalah autokorelasi.

Uji asumsi klasik yang terakhir adalah uji heteroskedastisitas yang bertujuan untuk menguji apakah dalam model regresi terjadi ketidaksamaan variance dari residual satu pengamatan ke pengamatan yang lain. Jika variance dari residual satu pengamatan ke pengamatan lain tetap, maka disebut homokedastisitas dan jika berbeda disebut heteroskedastisitas (Ghozali, 2013). Uji glejser adalah meregresi variabel bebas terhadap nilai Absolut Residual dari model utama. Apabila variabel bebas signifikan secara statistik, maka ada indikasi terjadi heteroskedastisitas. Hasil uji heteroskedastisi sebagai berikut: 
Tabel 6

Uji Glejser Heteroskedastisitas Coefficients $^{\mathrm{a}}$

\begin{tabular}{|c|c|c|c|c|c|c|}
\hline \multirow[t]{2}{*}{ Model } & \multirow[b]{3}{*}{ (Constant) } & \multicolumn{2}{|c|}{ Unstandardized Coefficients } & \multirow{2}{*}{$\begin{array}{c}\text { Standardized } \\
\text { Coefficients } \\
\text { Beta }\end{array}$} & \multirow[t]{2}{*}{$\mathrm{T}$} & \multirow[t]{2}{*}{ ig. } \\
\hline & & B & Std. Error & & & \\
\hline \multirow{4}{*}{1} & & .827 & .217 & & 3.802 & .000 \\
\hline & EQRAT & -2.633 & 1.810 & -.195 & -1.455 & .150 \\
\hline & EARNVOL & -11.838 & 13.915 & -.110 & -.851 & .398 \\
\hline & CREDITRISK & -.067 & .245 & -.034 & -.272 & .787 \\
\hline
\end{tabular}

a. Dependent Variable: RES2

Sumber : Data Olahan Sendiri menggunakan IBM SPSS Statistics 21.

Dari hasil Uji Glejser pada tabel 6 dapat diketahui bahwa nilai signifikansi keempat variabel yaitu modal (EQRAT) sebesar $0,150, \quad$ risiko kredit (CREDITRISK) 0,787, earning volatility (EARNVOL) sebesar 0,398. Dengan demikian dapat disimpulkan bahwa keempat variabel mempunyai signifikansi yang lebih besar dari 0,05. Artinya data dalam penelitian ini tidak terdapat masalah heteroskedastisitas pada model regresi.

\section{Uji kelayakan model (goodness of fit)}

Uji goodness of fit yang pertama yaitu uji koefisien determinasi $\left(\mathrm{R}^{2}\right)$ yang pada intinya mengukur seberapa besar kemampuan variabel independen dalam menjelaskan variasi yang terjadi dalam variabel dependen. Nilai koefisien determinasi adalah antara nol dan satu (Ghozali, 2013). Hasil selengkapnya dari uji determinasi $\left(\mathrm{R}^{2}\right)$ seperti pada tabel di bawah ini:

Tabel 7

Koefisien Determinasi $\left(\mathbf{R}^{2}\right)$ Model Summary ${ }^{\text {b }}$

\begin{tabular}{lcccc}
\hline Model & $\mathrm{R}$ & $\mathrm{R}$ Square & $\begin{array}{c}\text { Adjusted R } \\
\text { Square }\end{array}$ & $\begin{array}{c}\text { Std. Error of the } \\
\text { Estimate }\end{array}$ \\
\hline 1 & $.678^{\mathrm{a}}$ & .460 & .436 & .55032063 \\
\hline a. Predictors: (Constant), CREDITRISK, EARNVOL, EQRAT \\
b. Dependent Variable: LIQUIDITY \\
Sumber : Data Olahan Sendiri menggunakan IBM SPSS Statistics 21.
\end{tabular}

Dari tabel 7 dapat diperoleh bahwa nilai adjusted $\mathrm{R}^{2}$ sebesar 0,436 . Hal ini berarti 43,6\% variabel dependen yaitu liquidity creation dapat dijelaskan oleh variabel independen modal bank (EQRAT), risiko kredit (CREDIT RISK) dan earning volatility (EANVOL). Sedangkan sisanya sebesar 56,4\% (100\%-43,6\%) dijelaskan oleh variabel lain diluar model penelitian ini.
Yang kedua adalah uji statistik F yang dapat menunjukan apakah variabel independen dalam model regresi mempunyai pengaruh secara bersamasama terhadap variabel dependen. Dalam penelitian ini uji $\mathrm{F}$ bertujuan untuk melihat apakah variabel independen secara bersama-sama berpengaruh terhadap liquidity creation. Untuk lebih jelasnya dapat dilihat dari hasil Uji F dibawah ini: 
Tabel 8

Uji Signifikansi Simultan

ANOVA ${ }^{a}$

\begin{tabular}{llrrrrr}
\hline Model & & Sum of Squares & df & Mean Square & F & \multicolumn{1}{c}{ Sig. } \\
& Regression & 17.033 & 3 & 5.678 & 18.747 & $.000^{\mathrm{b}}$ \\
\cline { 2 - 7 } 1 & Residual & 19.988 & 66 & .303 & & \\
& Total & 37.021 & 69 & & & \\
\hline
\end{tabular}

a. Dependent Variable: LIQUIDITY

b. Predictors: (Constant), CREDITRISK, EARNVOL, EQRAT

Sumber : Data Olahan Sendiri menggunakan IBM SPSS Statistics 21.

Berdasarkan tabel 8 Uji Anova atau $F$ test menghasilkan nilai $\mathrm{F}$ hitung sebesar 18,747 dengan tingkat signifikansi 0,000 . Karena probabilitas signifikansi lebih kecil dari 0,05 maka model regresi dapat digunakan untuk memprediksi liquidity creation atau dapat dikatakan bahwa modal bank (EQRAT), risiko kredit (CREDITRISK) dan earning volatility (EARNVOL) secara bersama-sama berpengaruh terhadap Liquidity Creation.

Uji statistik $t$ bertujuan untuk mengetahui seberapa jauh pengaruh variabel independen secara individual dalam menerangkan variasi variabel dependen, hasil selengkapnya lihat tabel berikut:

Tabel 9

Uji Statistik t

Coefficients $^{\mathrm{a}}$

\begin{tabular}{|c|c|c|c|c|c|c|}
\hline \multirow[t]{2}{*}{ Model } & \multirow[b]{3}{*}{ (Constant) } & \multicolumn{2}{|c|}{ Unstandardized Coefficients } & \multirow{2}{*}{$\begin{array}{c}\text { Standardized } \\
\text { Coefficients } \\
\text { Beta }\end{array}$} & \multirow[t]{2}{*}{$\mathrm{T}$} & \multirow[t]{2}{*}{ ig. } \\
\hline & & B & Std. Error & & & \\
\hline \multirow{4}{*}{1} & & 4.572 & .385 & & 11.861 & .000 \\
\hline & EQRAT & -17.910 & 3.208 & -.569 & -5.583 & .000 \\
\hline & EARNVOL & -54.883 & 24.659 & -.219 & -2.226 & .029 \\
\hline & CREDITRISK & -.018 & .434 & -.004 & -.042 & .967 \\
\hline
\end{tabular}

a. Dependent Variable: LIQUIDITY

Sumber : Data Olahan Sendiri menggunakan IBM SPSS Statistics 21.

Dari tabel 9 menyatakan bahwa variabel modal bank (EQRAT) dan ketidakstabilan pendapatan (EARNVOL) berpengaruh negatif dan signifikan terhadap liquidity creation. Sementara itu risiko kredit (CREDITRISK) berpengaruh yang negatif namun tidak signifikan terhadap liquidity creation.

\section{Analisis regresi linear berganda}

Dari analisis asumsi klasik yang telah dilakukan sebelumnya diketahui bahwa data memenuhi persyaratan yang diantaranya adalah residual terdistribusi secara normal, tidak terjadi multikolinieritas, tidak terjadi autokorelasi dan tidak terjadi heteroskedastisitas sehingga dapat dilakukan analisis regresi berganda seperti pada tabel 9. Untuk itu model regresi berganda pada penelitian ini dapat disimpulkan dengan persamaan matematis sebagai berikut :

$L C=4,572-17,910$ EQRAT $-0,018$ CREDITRISK - 54,883 ERNVOL + e

Analisis pengaruh parsial dari persamaan regresi di atas memperlihatkan nilai konstanta (a) dalam persamaan regresi sebesar 4,572. Hal tersebut menyatakan bahwa jika variabel independen EQRAT, CREDIT RISK dan EARNVOL sama dengan nol, maka nilai liquidity creation sebesar 4,572. Nilai Koefisien regresi modal bank (EQRAT) sebesar -17,910. Hal 
tersebut menyatakan bahwa setiap pertambahan 1 satuan pada variabel modal bank (EQRAT) akan menurunkan liquidity creation sebesar 17,910 poin. Nilai Koefisien regresi risiko kredit (CREDITRISK) sebesar -0,018. Hal tersebut menyatakan bahwa setiap pertambahan 1 satuan pada variabel risiko bank akan menurunkan liquidity creation sebesar 0,018 poin. Nilai Koefisien regresi pada earning volatility sebesar $-54,883$ menyatakan bahwa setiap pertambahan 1 satuan variabel pada ketidakpastian pendapatan akan diikuti dengan penurunan liquidity creation sebesar 54,883 poin.

\section{HASIL PENELITIAN DAN PEMBAHASAN}

Berdasarkan uji statistik di atas hasil koefisien regresi untuk variabel modal bank (EQRAT) adalah sebesar 17,910 dengan signifikansi sebesar 0,000 lebih rendah dari 0,05. Hal tersebut berarti bahwa variabel EQRAT berpengaruh negatif dan signifikan terhadap variabel liquidity creation, sehingga dapat diambil kesimpulan bahwa $\mathrm{H}_{1}$ diterima.

Berdasarkan uji di atas hasil koefisien regresi untuk variabel risiko kredit (CREDITRISK) adalah sebesar 0,018 dengan signifikansi sebesar 0,967 lebih besar dari 0,05 . Hal tersebut berarti variabel berpengaruh negatif namun tidak signifikan terhadap variabel risiko kredit, sehingga dapat diambil kesimpulan bahwa $\mathrm{H}_{2}$ ditolak.

Berdasarkan uji di atas hasil koefisien regresi untuk variabel earning volatility (EARNVOL) adalah sebesar 54,883 dengan signifikansi sebesar 0,029 lebih rendah dari 0,05 . Hal tersebut berarti variabel earning volatility berpengaruh negatif dan signifikan terhadap variabel liquidity creation. Namun hasil tersebut tidak sesuai dengan hipotesis pada penelitian ini, untuk itu $\mathrm{H}_{3}$ ditolak.

\section{KESIMPULAN}

Analisis statistik koefisien determinasi $\mathrm{R}^{2}$ dalam penelitian ini menunjukan bahwa pengaruh variabel independen terhadap liquidity creation mempunyai determinasi $\left(\mathrm{R}^{2}\right)$ sebesar 0,436 atau $43,6 \%$. Hal ini berarti variasi liquidity creation dapat dijelaskan sebesar 43,6\% oleh variabel independen modal bank (EQRAT), risiko kredit (CREDIT RISK) dan ketidakstabilan pendapatan (EANVOL). Sedangkan sisanya $56,4 \% \quad(100 \%-43,6 \%)$ dijelaskan oleh variabel lain diluar model penelitian.

Modal bank (EQRAT) mempunyai pengaruh yang negatif dan signifikan terhadap liquidity creation. Hasil ini berarti sesuai dengan hipotesis pertama dalam penelitian ini sehingga mendukung teori financial fragilitycrowding out yang menyatakan bahwa modal bank yang tinggi akan menurunkan liquidity creation (Diamond and Rajan, 2000, 2001; Gorton dan Winton, 2000). Selain itu, hasil penelitian ini juga sejalan dengan hasil dari penelitian yang dilakukan oleh Lei dan Song (2013) dan Horváth et al., (2012). Bahwa pertambahan modal akan menurunkan liquidity creation. Begitu pula seperti apa yang terjadi di Indonesia 2007-2013 yang tercermin dari 10 bank besar, pertambahan modal akibat meningkatnya DPK telah menurunkan likuiditas pada perbankan tersebut.

Ketidakstabilan pendapatan (earning volatility) berpangaruh negatif dan signifikan terhadap liquidity creation. Karena pengaruh earning volatility terhadap liquidity creation adalah negatif. Maka hasil ini menolak hipotesis ketiga dalam penelitian ini yang menyatakan bahwa pengaruh earning volatility terhadap liquidity creation adalah positif. Namun hasil dalam penelitian ini sejalan dengan hasil dari penelitian yang dilakukan oleh Lei dan Song (2013) yang menyatakan 
bahwa earning volatility berpengaruh negatif terhadap liquidity creation. Artinya, semakin rendah tingkat earning volatility maka bank akan meningkatkan liquidity creation.

Risiko kredit berpengaruh negatif dengan nilai koefisien sebesar $-0,018$ namun tidak signifikan terhadap liquidity creation dengan nilai sig. sebesar 0,967. Hasil tersebut menolak hipotesis awal dalam penelitian ini yaitu risiko kredit berpengaruh positif terhadap liquidity creation. Sementara itu hasil dalam penelitian ini tidak konsisten dengan penelitian Horváth et al., (2012); Lei dan Song (2013) yang menyatakan bahwa hubungan risiko kredit dengan liquidity creation adalah positif.

Dalam penelitian ini hanya menggunakan tiga variabel independen untuk mempengaruhi liquidity creation. Karena mungkin banyak faktor lain yang mempengaruhi liquidity creation di luar model dalam penelitian ini seperti kinerja bank, risiko investasi dan lainnya. Selain itu, penelitian ini menggunakan subyek yang terbatas yaitu 10 bank besar pada tahun 2013, yang mungkin belum bisa digeneralisasikan pada seluruh perbankan di Indonesia dimana ada klasifikasi bank lain seperti bank menengah dan bank kecil.

Berdasarkan hasil yang diperoleh dari penelitian ini menunjukan bahwa modal bank (EQRAT) dan ketidakstabilan pendapatan (earning volatility) berpengaruh negatif dan signifikan terhadap tingkat penyediaan likuiditas (liquidity creation) pada bank.

Untuk manajemen bank, ketika manajemen bank ingin memenuhi tingkat penyediaan likuiditas (liquidity creation) pada bank, maka manajemen bank dapat mengontrol tingkat aktivitas pembiayaan ekuitas pada aset bank tersebut. Jika semakin rendah tingkat pembiayaan ekuitas pada aset bank maka akan meningkatkan tingkat penyediaan likuiditas (liquidity creation). Untuk itu, jika manajemen bank ingin meningkatkan tingkat penyediaan likuiditas (liquidity creation), maka manajemen bank diharapkan mampu menurunkan tingkat ekuitas yang digunakan untuk pembiayaan aset pada bank tersebut. Selain itu, manajemen bank juga dapat meningkatkan tingkat penyediaan likuiditas (liquidity creation), yaitu dengan memperhatikan tingkat ketidakstabilan pendapatan (earning volatility). Jika manajemen bank ingin meningkatkan tingkat penyediaan likuiditas (liquidity creation), maka diharapkan manajemen bank mampu menurunkan tingkat ketidakstabilan pendapat (earning volatility) pada bank tersebut

Untuk calon nasabah, ketika calon nasabah ingin menyimpan dananya di bank dan berharap dana yang disimpan itu aman sehingga dapat diambil sewaktu-waktu. Maka calon nasabah membutuhkan bank dengan tingkat penyediaan likuiditas (liquidity creation) yang tinggi. Dari hasil dalam penelitian ini, calon nasabah bisa melihat tingkat penyediaan likuiditas (liquidity creation) yang tinggi yaitu dari aktivitas pembiayaan modal yang rendah pada aset bank tersebut. Jika tingkat aktivitas pembiayaan modal pada aset bank tersebut rendah, maka calon deposan bisa memastikan bahwa pada bank tersebut mempunyai tingkat penyediaan likuiditas (liquidity creation) yang tinggi. Selain itu, calon nasabah juga bisa menentukan bank yang mempunyai tingkat penyediaan likuiditas (liquidity creaion) tinggi, yaitu dengan melihat dari rendahnya tingkat ketidakstabilan pendapatan (earing volatility) pada bank tersebut. Jika tingkat ketidakstabilan pendapatan rendah maka calon nasabah bisa mengetahui bahwa pada bank tersebut mempunyai tingkat penyediaan likuiditas yang tinggi. 
Untuk akademisi, diharapkan
untuk penelitian menggunakan variabel independen yang lain seperti kinerja bank, risiko investasi, tingkat efisiensi bank dan mengklasifikasikan perhitungan liquidity creation pada bank besar, bank menengah dan bank kecil.

\section{REFERENSI}

Bhattacharya, Sudipto, dan Anjan V. Thakor. 1993. Contemporary Banking Theory. Journal of Financial Intermediation 3, 2-50.

Beger, Allen N., and Christa H.S. Bouwman. 2007. Bank Liquidity Creation. Board of Governors of Federal reserve system and Wharton Financial Institution Center.

Berger, Allen N., and Christa H.S. Bouwman. 2006. The Measurement of Bank Liqudity Creation and the Effect of Capital. Board of Governors of the Federal Reserve System and Wharton Financial Institutions Center.

Berger, Allen N., Christa H.S. Bouwman, Thomas kick and Klaus Schaeck. 2013. Bank Risk Taking and Liquidity Creation following Regulatory Intervention and Capital Support.

Darmadji, Tjitono., dan Hendy M. Fakhruddin. 2001. Pasar Modal di Indonesia Pendekatan Tanya Jawab. Jakarta : Salemba Empat.

Diamond, D., dan R. Rajan. 2000. A Theory of Bank Capital. Journal of Finance 55, 2431-65.

Diamond, D., dan R. Rajan. 2001. Liquidity Risk, Liquidity Creation, and Financial Fragility: A Theory of Banking. Journal of Political Economy 109, 287-327.

Diamond, Douglas W. and Philip H. Dybvig. 1983. "Bank Runs, Deposit Insurance, and Liquidity". The University of Chicago Press.

Distinguin, Isabelle. Caroline Roulet and Amine Tarazi. 2011. "Bank Capital Buffer and Liquidity: Evidence from US and European publicly traded Banks". France : Université de Limoges, LAPE, 5 rue Félix Eboué, 87031 Limoges Cedex.

Fungáčová, Zuzana. Laurent Weill and Mingming Zhou. 2010. "Bank Capital, Liquidity Creation and Deposit Insurance". Bank of Finland - Institute for Economies in Transition (BOFIT) discussion paper no 17/2010.

Ghozali, Imam. 2013. Aplikasi Analisis Multivariate dengan Program IBM SPSS 21 "Update PLS Regresi". Semarang : Badan Penerbit Universitas Diponegoro.

Gorton, Gary and Andrew Winton. 2000. Liquidity Provision, Bank Capital, and Macroeconomy.Penerbit : University of Minnesota Working Paper.

Hanniffy, Gary. 2014. Posisi 10 Bank Terbesar Tetap Kuat di 2014. http://pefindo.com

Horváth, Roman., Jakub Seidler and Laurent Weill. 2012. Bank Capital and Liquidity Creation "Granggger-Casulity Evidence". Macroprudential Research Network.

Lei, Adrian C.H dan Zhouyun Song. 2013. Liquidity Creation and Bank Capital Structure in China. Macau: Faculty of Business Administration, University of Macau.

Latumaerissa, Julius R. 2011. Bank dan Lembaga Keuangan Lain. Jakarta: Salemba Empat.

Mishkin, Frederic S. 2008. Ekonomomi Uang, Perbankan, dan Pasar Keuangan. Jakarta : Salemba Empat.

Siamat, Dahlan. 2005. Manajemen Lembaga Keuangan. Jakarta : Lembaga Penerbit Fakultas Ekonomi Universitas Indonesia.

Sugiyono. 2008. Metode Penelitian Bisnis (pendekatan kuantitatif, kualitatif dan R\&D). Bandung : Alfabeta.

Sugiyono. 2010. Metode Penelitian Bisnis. Bandung : Alfabeta

Suyatno, Thomas dkk. 1993. Kelembagaan Perbankan. Jakarta : PT Gramedia Pustaka Utama. 
Taswan. 2006. Manajemen Perbankan Konsep, Teknik dan Aplikasi. Yogyakarta : UPP STIM YKPM Yogyakarta.

Turisman, teguh dan Darto Wiryosukarto. 2014. "120 Rating bank 2014”. Infobank, No. 423 Juni 2014, Vol XXXVI.

Van Greuning, Hennie., dan Bratanovic, Sonja Brajovic. 2011. Analisis Risiko Perbankan. Edisi Ketiga, Jakarta: Salemba Empat.

Yong Jia, Lin. 2013. "Bank Capital and Liquidity Creation in Asia pacific". Tokyo : Financial Management Association (FMA) Asian Doctoral Student Consortium. 